Dejan Kantar ${ }^{1}$
Katedra za
psihologiju,
Filozofski fakultet,
Univerzitet u
Banjoj Luci

Marija Zotović Odsek za psihologiju, Filozofski fakultet, Univerzitet $u$ Novom Sadu

Siniša Subotić
Katedra za
psihologiju
i Prirodno-
matematički
fakultet, Univerzitet
u Banjoj Luci

1 Adresa autora: dejan.kantar@ff.unibl.org

Primljeno: 27. 12. 2019. Primljena korekcija: 06. 04. 2020. Prihvaćeno za štampu: 28. 05. 2020.

\section{POLNE RAZLIKE U PREFERENCIJAMA PREMA OSOBINAMA IDEALNOG PARTNERA I ULOGA AFEKTIVNE VEZANOSTI}

Prvi cilj ovog istraživanja jeste ispitati koje psihološke karakteristike idealnog partnera vrednuju ženske i muške osobe u ranoj odrasloj dobi. Drugi cilj jeste utvrditi mogu li se potencijalne razlike u preferencijama prema osobinama idealnog partnera predvidjeti na osnovu izraženosti dimenzija afektivne vezanosti: anksioznosti i izbjegavanja. Prigodan uzorak čini 279 heteroseksualnih studenata $(51.6 \%$ djevojaka), prosječnog uzrasta 20.33 godine. Ispitanici su popunili Modifikovanu skalu iskustava u bliskim odnosima (SM-ECR-R) te BSRI inventar polne uloge, koji je korišćen kao mjera poželjnih partnerskih osobina. Rezultati pokazuju da su djevojke i mladići uglavnom usaglašeni u pogledu stepena poželjnosti većine osobina idealnog partnera. Kao poželjne birane su i ekspresivne i instrumentalne osobine, s tim da je uočena snažnija preferencija prema prvim. I djevojke i mladići poželjnijim idealnim partnerima smatraju emotivno ekspresivnije osobe, s tim da djevojke svoje idealne partnere opisuju preko viših vrijednosti i na mjerama socijalne dominacije i na mjerama emotivne ekspresivnosti. Razmatranjem individualnih razlika preko dimenzija afektivnog vezivanja utvrđeno je da višu preferenciju prema socijalnoj dominaciji predviđaju niže izbjegavanje i niža anksioznost, dok višu preferenciju prema emotivnoj ekspresivnosti predviđaju niže izbjegavanje i viša anksioznost. Ovim je potvrđeno da teorija afektivnog vezivanja predstavlja koristan koncept u objašnjenju preferencija prema osobinama idealnog partnera, pri čemu je intenzitet predikcije osjetno veći u slučaju emotivne ekspresivnosti nego socijalne dominacije.

Ključne riječi: idealan partner, instrumentalne osobine, ekspresivne osobine, dimenzije afektivne vezanosti, rana odrasla dob 


\section{Uvod}

Proširenje teorije afektivnog vezivanja, kojim su, pored ranih iskustava, obuhvaćeni i odnosi s odraslim ljudima (Hazan \& Shaver, 1987), uticalo je na to da ona postane pogodan konceptualni okvir za razumijevanje partnerskih relacija. To potvrđuje činjenica da je posljednjih nekoliko decenija identifikacija individualnih razlika zasnovanih na kvalitetama afektivnog vezivanja jedan od najčešćih istraživačkih ciljeva u psihologiji partnerskih relacija.

U prvim istraživanjima ovog fenomena konceptualizovane su različite kategorije odnosno tipovi vezanosti, kao što su jedan sigurni i tri nesigurna - odbacujući, preokupirani i bojažljivi (Bartholomew \& Horowitz, 1991). Međutim, nakon mnogih debata u vezi s načinom na koji je najpogodnije mjeriti kvalitet afektivnog vezivanja odraslih, posebno u partnerskim odnosima (npr. Fraley et al., 2000), dimenzionalni pristup postao je izbor najvećeg broja istraživača (Mikulincer \& Shaver, 2016). Tim se pristupom razlike među ljudima određuju kao varijacije duž dvije dimenzije - anksioznosti i izbjegavanja - koje karakterišu kvalitet afektivnih veza u odrasloj dobi, a reprezentuju doživljaj sebe (dimenzija anksioznosti) i doživljaj drugih (dimenzija izbjegavanja) u bliskim odnosima (Brennan et al., 1998). Dimenzija anksioznosti podrazumijeva strah od odbacivanja, napuštanja i samoće, tj. određuje se kao prevelika potreba za bliskošću, prihvatanjem, podrškom, sigurnošću i uvjeravanjem u ljubav. Osobe kod kojih je izražena ova dimenzija često se ponašaju zavisno u međuljudskim odnosima i brinu da im drugi neće biti dostupni u teškim situacijama. Dimenzija izbjegavanja odnosi se na stepen neprijatnosti u odnosima, prilikom otvaranja, izražavanja emocija i zavisnosti. Karakterišu je plašljivost, nedostatak traženja prisnosti u relacijama te sumnja u motive i namjere drugih, pa osobe koje postižu visoke skorove na ovoj dimenziji obično održavaju emocionalnu distancu u odnosima (Feeney, 1999; Mikulincer \& Shaver, 2016). Ako se ovakvo tumačenje vezanosti sagleda u svjetlu pomenutih tipova afektivnog vezivanja, moglo bi se reći da pojedinci koji postižu niske skorove na objema dimenzijama imaju razvijen siguran stil, dok sve druge kombinacije ukazuju na nesigurnu vezanost.

Razlike u kvalitetu afektivnog vezivanja ispoljavaju se u svakoj fazi razvoja partnerskog odnosa, od početnog flertovanja i upoznavanja, pa sve do uspostavljanja i održavanja dugoročnog odnosa (Mikulincer \& Shaver, 2016). One podrazumijevaju i određene preferencije kad je riječ o izboru partnera. U velikom broju studija testirane su tri hipoteze u vezi sa partnerskim afektivnim vezivanjem (npr. Holmes \& Johnson, 2009): 1) o podudarnosti stilova afektivnog vezivanja, 2) o komplementarnosti stilova afektivnog vezivanja te 3) o preferenciji prema sigurnosti. Iako su sve navedene hipoteze dobile empirijsku podršku, u najvećem broju istraživanja uočeno je da su ispitanici, bez obzira na sopstveni stil, prednost davali potencijalnim partnerima sa sigurnim stilom afektivnog vezivanja (Mikulincer \& Shaver, 2016). Međutim, posjedovanje određenih osobina može uticati na atraktivnost potencijalnih partnera 
različitih kvaliteta vezivanja. Tako se pokazalo da su visoko izbjegavajuće osobe sklone laskanju procijenjene kao privlačnije nego sigurno vezane koje ne iskazuju takvu sklonost (Brumbaugh et al., 2014).

Pitanje zašto ljudi biraju određene osobe za partnere jedno je od najstarijih i najsloženijih u psihologiji bliskih odnosa. Kriterijumi kojima se ljudi rukovode prilikom izbora partnera bili su predmet i mnogih istraživanja koja ne polaze iz ugla teorije afektivnog vezivanja, a većini njih cilj je bila identifikacija faktora koji se nalaze u osnovi velikog broja različitih preferencija (Atari \& Jamali, 2016). Treba pritom imati u vidu da su se ove studije međusobno razlikovale, kako prema broju i tipu ispitivanih karakteristika (Shackelford et al., 2005), tako i prema karakteristikama uzorka (npr. Atari \& Jamali, 2016). Uprkos ovim metodološkim razlikama, mogu se uočiti opšti zaključci. Naime, neka od tih istraživanja, slično onima koja su zasnovana na teoriji afektivnog vezivanja, potvrđuju da se u najpoželjnije osobine potencijalnih partnera ubrajaju one koje odlikuju sigurno vezane osobe, kao što su: pouzdanost, toplina, povjerenje i emocionalna stabilnost (Botwin et al., 1997).

Među pripadnicima oba pola iz različitih kultura uočen je relativno visok nivo poželjnosti nekih partnerskih, uglavnom psiholoških osobina, poput: pouzdanosti, emocionalne stabilnosti i zrelosti, ljubaznosti, inteligencije, iskrenosti i smisla za humor, ali i fizičkih karakteristika, kao što je dobro zdravlje (Buss et al., 2001; Boxer et al., 2013). Za neke druge osobine ustanovljena je malo veća polna ili kulturna zavisnost. Tako istraživanja pokazuju da i žene i muškarci vrednuju fizičku privlačnost i materijalni status potencijalnog partnera (Buss et al., 1990; Buss et al., 2001; Boxer et al., 2013), ali da se najveće razlike mogu uočiti u težnji muškaraca da akcentuju fizički izgled i atraktivnost potencijalnih partnerki, odnosno tendenciji žena da visoko vrednuju materijalni status potencijalnih partnera. Ipak, važno je istaći kako kroskulturalne studije pokazuju da je izbor osobina poželjnog partnera uslovljen više kulturom nego polom ispitanika (Buss et al., 1990). Tako je u jednom istraživanju koje je obuhvatalo ispitanike iz 33 zemlje (Buss et al., 1990) uočeno da se u zemljama Azije visoko vrednuje nevinost potencijalnog partnera, dok se u zapadnoevropskim ona smatra manje važnom u odnosu na druge osobine.

Većina nalaza govori da su muškarci i žene saglasni oko izbora najpoželjnijih psiholoških osobina, premda se razlike mogu prepoznati $u$ značaju koji im se pripisuje (Botwin et al., 1997; Lippa, 2007; Simpson et al., 2001). Uprkos ustaljenim vjerovanjima da žene preferiraju dominantne muškarce (npr. Snyder et al., 2008), otkriveno je da oba pola manje favorizuju osobine koje se povezuju s dominacijom nego one koje su u vezi s ljubaznošću i pouzdanošću (Botwin et al., 1997; Fletcher et al., 1999). Stoga bi se moglo reći kako se slika idealnog partnera ne poklapa s opštim uvjerenjima o tipičnim karakteristikama muškaraca. Diskrepancu između osobina poželjnog partnera i tipičnog muškarca indirektno potvrđuju i nalazi autora s naših prostora (Vuletić i Vuletić, 2017). 
Iako rezultati pojedinih istraživanja pokazuju da se rodno specifični atributi mogu izmijeniti zbog promjena u društvenim ulogama i društvenoj dinamici (Diekman \& Eagly, 2000), u jednoj recentnoj studiji utvrđeno je da su neki rodni stereotipi prisutni jednako kao i prije 30 godina (Haines et al., 2016). Tako ljudi i dalje snažno stereotipiziraju muškarce i žene, ne samo prema ponašanjima, zanimanjima i fizičkim karakteristikama već i prema osobinama ličnosti.

Muškarcima se obično pripisuju osobine povezane s djelovanjem (engl. agentic), kao što su dominantnost, asertivnost, visoko samopouzdanje, agresivnost i ambicioznost. S druge strane, ženama se pripisuju osobine povezane s brigom o drugima (engl. communal), poput ljubaznosti, brižljivosti, osjetljivosti na potrebe drugih, nježnosti i saosjećajnosti (npr. Bem, 1974; Bosak et al., 2017). Neki su autori ove "tipične" muške osobine označavali terminom maskulinost, a ženske terminom femininost (Bem, 1974). Drugi su takvo viđenje problematizovali (Abele \& Wojciszke, 2007; Fiske et al., 2002), budući da se terminima maskulinost i femininost označavaju složeniji koncepti koji, osim osobina, uključuju i druge aspekte, poput interesovanja, stavova, fizičkog izgleda (Kachel et al., 2016; Levy et al., 1995). S tim u vezi, predložili su da se za označavanje skupova osobina koji se po tradiciji pripisuju muškarcima i ženama koriste manje opšti termini - instrumentalnost i ekspresivnost (Choi \& Fuqua, 2003). U upotrebi su još specifičniji termini, proizašli iz prihometrijski orijentisanih istraživanja, a kojima se u nekoj mjeri preciznije opisuju isti ili slični skupovi osobina. Takvi su: dominacija, socijalna dominacija i asertivnost, pod kojima se podrazumijevaju osobine poput snažne ličnosti, spremnosti na zauzimanje stava, ambicioznosti, asertivnosti (Moreland et al., 1978), zatim termin autonomija, koji uključuje samopouzdanost, nezavisnost, snažnu ličnost, samostalnost, individualnost i sl. (Maznah \& Choo, 1986), te ekspresivnost, emotivna ekspresivnost odnosno interpersonalna senzitivnost, kojima se označavaju skupovi osobina kao što su nježnost, osjetljivost na tuđe potrebe, brižnost, ljubaznost, razumijevanje, saosjećajnost (Moreland et al., 1978; Pedhazur \& Tetenbaum, 1979) i dr.

\section{Ciljevi istraživanja}

U fokusu ovog istraživanja jesu karakteristike koje osobe mlađe odrasle dobi iz Republike Srpske vide kao najpoželjnije kod potencijalnih emotivnih partnera. Problematici se pristupa sa stanovišta teorije afektivne vezanosti.

Prvi cilj jeste ustanoviti koje psihološke karakteristike partnera vrednuju osobe u ranoj odrasloj dobi, a u okviru toga ispitati polne razlike u odabiru poželjnih karakteristika. Na osnovu teorijskog okvira i rezultata prethodnih istraživanja, očekuje se da će djevojke i mladići uglavnom biti saglasni oko izbora poželjnih psiholoških osobina partnera, ali da će u manjoj mjeri favorizo- 
vati instrumentalne osobine, poput dominacije, a u većoj mjeri ekspresivne osobine, kao što je ljubaznost.

S obzirom na postavke teorije afektivnog vezivanja i nalaze koji sugerišu da je kvalitet nečije afektivne vezanosti važan prilikom biranja partnera, drugi cilj istraživanja, proizašao i iz činjenice da u dostupnim bazama naučnih časopisa nisu pronađena istraživanja koja direktno povezuju kvalitet afektivnog vezivanja sa osobinama idealnog partnera, jeste utvrditi mogu li se preferencije prema osobinama idealnog partnera objasniti preko dimenzija anksioznosti i izbjegavanja. Biće ispitano i da li pol ispitanika eventualno moderira te relacije.

\section{Metod}

\section{Uzorak i postupak ispitivanja}

Uzorak u ovom istraživanju prigodnog je tipa i inicijalno je podrazumijevao 298 studenata Univerziteta u Banjoj Luci. Trebalo je da oni na osnovu ponuđene liste osobina opišu svog idealnog partnera i popune upitnik za procjenu kvaliteta afektivne vezanosti. Manji broj njih $(N=19)$ kao idealnog partnera opisivao je osobu istoga pola. Pošto je uočeno da homoseksualne žene i muškarci imaju donekle specifične preferencije kada je riječ o partnerskim karakteristikama (Lippa, 2007), a u uzorku ih je bilo nedovoljno za zasebnu obradu, odlučeno je da podaci tih studenata ne budu uključeni u analizu. Tako konačni uzorak u ovom istraživanju čini 279 heteroseksualnih studenata - 144 ženskog i 135 muškog pola - čiji je prosječni uzrast 20.33 godine $(S D=1.25)$.

Ispitivanje je obavljeno u prostorijama u kojima studenti inače pohađaju nastavu, a za vrijeme ispunjavanja upitnikâ ispitivač je bio u prostoriji, pa su ispitanici imali i mogućnost da razjasne sve eventualne nedoumice. Prije nego što su upitnici podijeljeni studentima koji su pristali da učestvuju u istraživanju, objašnjeni su svrha i cilj ispitivanja, a naglašeno je kako je ispitivanje anonimno. 


\section{Instrumenti}

\section{Modifikovana skala iskustava u bliskim odnosima (Serbian Version of Modified and Revised Experiences in Close Relationships Scale; SM-ECR- R)}

Skala SM-ECR-R (Fraley et al., 2000; adaptacija Hanak \& Dimitrijević, 2013) korišćena je za procjenu partnerske afektivne vezanosti. Riječ je o verziji istoimenog instrumenta kreiranog za procjenu individualnih razlika afektivne vezanosti odraslih u pogledu dimenzije anksioznosti (strah od odbacivanja i napuštanja) i dimenzije izbjegavanja (nelagodnost zbog bliskosti i zavisnosti od drugih). Skala sadrži ukupno 36 tvrdnji, koje opisuju različita osjećanja i stavove prema sebi i partneru, a ispitanici, služeći se skalom od 1 (nimalo se ne slažem) do 7 (potpuno se slažem), treba da izraze stepen saglasnosti sa svakom tvrdnjom. Pošto se jedna polovina tvrdnji odnosi na dimenziju anksioznosti, a druga na dimenziju izbjegavanja, na osnovu zbira odgovora ispitanika dobijaju se kontinuirani skorovi za pomenute dimenzije. Ukupan rezultat na svakoj supskali može varirati u rasponu od 18 do 126, pri čemu veće vrijednosti ukazuju na veću izraženost dimenzija. Obje supskale imaju visoku unutrašnju konzistentnost: $\alpha=.87 \mathrm{i} \omega=.89$ za anksioznost i $\alpha=\mathrm{i} \omega=.88$ za izbjegavanje.

\section{Inventar polne uloge (Bem Sex Role Inventory; BSRI) primijenjen kao inventar poželjnih osobina idealnog partnera}

BSRI (Bem, 1974, 1981) je jedan od najkorišćenijih instrumenata za mjerenje rodnih uloga, a sastoji se od 60 stavki - dvadeset pridjeva kojima se označavaju tipične osobine muškaraca, dvadeset pridjeva kojima se označavaju tipične osobine žena te dvadeset pridjeva kojima se označavaju rodno neutralne osobine, a koji imaju status filer ajtema (Bem, 1981). S obzirom na to da BSRI predstavlja opsežnu listu tipičnih osobina oba pola, instrument je u ovom radu korišćen za procjenu poželjnih osobina idealnog partnera. Zadatak ispitanika je bio da na sedmostepenoj Likertovoj skali (od nimalo se ne slažem do potpuno se slažem) procijene u kojoj mjeri svaka od osobina opisuje njihovog idealnog partnera, tj. koje bi osobine ta osoba trebalo da posjeduje.

Iako je BSRI kreiran da mjeri koncepte maskulinosti i femininosti, njime su zapravo obuhvaćeni skupovi osobina koje su pojedini autori nazivali drugim terminima, npr. dominacijom i ekspresivnošću. Međutim, budući da su uočene nekonzistentnosti u nalazima koji se odnose na broj i sadržaj faktora BSRI (Choi \& Fuqua, 2003), prije vršenja glavnih analiza bilo je neophodno provjeriti koja latentna struktura instrumenta, tj. operacionalizacija dimenzija, najviše odgovara podacima iz ovog istraživanja. Serijom konfirmativnih faktorskih analiza (WLSMV/DWLS postupci) sprovedenih u programu „lavaan” za R 
(Rosseel, 2012) provjereni su različiti BSRI faktorski modeli sa pretpostavljena dva, tri ili četiri faktora koja su najčešće opisivana u literaturi (Choi \& Fuqua, 2003; Waters et al., 1977).

Svaki od inicijalno testiranih modela imao je izuzetno loš fit prema konvencionalnim kriterijumima (Hooper et al., 2008), uz veliki broj ajtema sa niskim zasićenjima. Nakon njihove etapne redukcije, u konkurenciji modela sa dva, tri i četiri pretpostavljena faktora, postignut je najbolji fit redukovanog dvofaktorskog modela sa 21 stavkom (Prilog, Tabela A): $\chi^{2}(188)=422.43, p<$ $.001, \mathrm{CFI}=.93, \mathrm{TLI}=.93, \mathrm{RMSEA}=.07,90 \%$ CI $[.06, .08], \mathrm{SRMR}=.07$. Korelacija faktora na nivou sumacionih skorova iznosi $r=.40, p<.01$.

$\mathrm{S}$ obzirom na kvalitet stavki koje ulaze u sastav faktora, oni su nazvani Socijalnom dominacijom (9 ajtema; $\mathrm{M}_{\Lambda}=.57 ; \alpha=.82 i \omega=.79$ ) i Emotivnom ekspresivnošću (12 ajtema; $M_{\Lambda}=.67 ; \alpha=.90 \mathrm{i} \omega=.88$ ), a to su termini koji su već korišćeni u drugim istraživanjima (Choi \& Fuqua, 2003). Za potrebe ispitivanja relacija sa dimenzijama afektivne vezanosti upotrijebljeni su sumacioni skorovi osobina koje su zadržane na ovim faktorima, dok su za provjere polnih razlika prema idealnim osobinama korišćene i sve individualne BSRI stavke, osim filera.

\section{Rezultati}

\section{Razlike u preferiranim osobinama idealnih partnera kod mladića i djevojaka}

Preferiranje idealnih partnera sagledano na nivou pojedinačnih osobina BSRI inventara prikazano je u Tabeli 1. U grupi najpoželjnijih našle su se pretežno ekspresivne osobine, poput: odanosti, pozitivnosti, razumijevanja, ljubaznosti, nježnosti i ljubavi prema djeci, ali i određene instrumentalne osobine, kao što su: samostalnost, ambicioznost, snažna ličnost i asertivnost.

Tabela 1

Karakteristike idealnih partnera razvrstane prema poželjnosti

\begin{tabular}{|c|c|c|c|c|c|}
\hline Karakteristike idealnog momka & $M$ & $S D$ & Karakteristike idealne djevojke & $M$ & $S D$ \\
\hline Odan $^{b}$ & 6.68 & 0.61 & Pozitivnab $^{b}$ & 6.55 & 0.82 \\
\hline Ima razumijevanja ${ }^{b}$ & 6.56 & 0.78 & Odanab & 6.51 & 0.92 \\
\hline Pozitivan ${ }^{b}$ & 6.56 & 0.79 & Ima razumijevanjab & 6.31 & 0.80 \\
\hline Ljubazan $^{b}$ & 6.49 & 0.71 & Ljubazna $^{b}$ & 6.25 & 0.97 \\
\hline Brižan $^{b}$ & 6.24 & 0.89 & Ambiciozna $^{a}$ & 6.10 & 0.93 \\
\hline Samostalan $^{\mathrm{a}}$ & 6.24 & 0.92 & Ženstvena & 6.08 & 1.22 \\
\hline Ambiciozan $^{\mathrm{a}}$ & 6.22 & 0.86 & Voli djecub ${ }^{b}$ & 6.07 & 1.32 \\
\hline Snažna ličnost ${ }^{a}$ & 6.21 & 1.03 & Prijatna u komunikaciji ${ }^{b}$ & 6.01 & 1.10 \\
\hline
\end{tabular}




\begin{tabular}{|c|c|c|c|c|c|}
\hline Voli djecub & 6.17 & 1.19 & Nježnab & 6.01 & 1.16 \\
\hline Nježan $^{b}$ & 6.12 & 0.97 & Snažna ličnost ${ }^{\mathrm{a}}$ & 5.99 & 1.09 \\
\hline Saosjećajan ${ }^{b}$ & 6.06 & 0.93 & Brižnab & 5.96 & 1.05 \\
\hline Osjećajan ${ }^{b}$ & 6.03 & 0.95 & Saosjećajna ${ }^{b}$ & 5.96 & 1.13 \\
\hline Topla osobab & 6.03 & 1.00 & Samopouzdana ${ }^{a}$ & 5.89 & 1.07 \\
\hline Asertivan $^{\mathrm{a}}$ & 6.02 & 1.08 & Asertivna $^{a}$ & 5.87 & 1.01 \\
\hline Prijatan u komunikaciji ${ }^{\text {b }}$ & 5.99 & 1.05 & Osjećajna ${ }^{b}$ & 5.87 & 1.22 \\
\hline Spreman da zauzme stav & 5.99 & 1.01 & Brani sopstvena uvjerenja & 5.79 & 1.15 \\
\hline Muževan & 5.97 & 1.23 & Topla osobab & 5.73 & 1.19 \\
\hline Samopouzdan ${ }^{\mathrm{a}}$ & 5.88 & 0.97 & Spremna da zauzme stav ${ }^{a}$ & 5.71 & 1.06 \\
\hline Brani sopstvena uvjerenja & 5.88 & 1.03 & Samostalna ${ }^{a}$ & 5.62 & 1.15 \\
\hline $\begin{array}{l}\text { Sposoban da ublaži tuđu } \\
\text { povrijeđenost }^{\mathrm{b}}\end{array}$ & 5.76 & 1.05 & Nezavisna $^{a}$ & 5.25 & 1.60 \\
\hline Nezavisan $^{\mathrm{a}}$ & 5.68 & 1.28 & $\begin{array}{l}\text { Sposobna da ublaži tuđu } \\
\text { povrijeđenost }^{\mathrm{b}}\end{array}$ & 5.24 & 1.47 \\
\hline Spreman da rizikuje & 5.47 & 1.10 & Sportskog duha & 5.22 & 1.54 \\
\hline Ne koristi grube riječi & 5.27 & 1.53 & Analitična & 5.18 & 1.31 \\
\hline Sportskog duha & 5.14 & 1.43 & Spremna da rizikuje & 5.16 & 1.30 \\
\hline Analitičan & 4.91 & 1.44 & Moćna $^{a}$ & 4.95 & 1.49 \\
\hline Osjetljiv na tuđe potrebe & 4.81 & 1.45 & Takmičarski nastrojena & 4.56 & 1.68 \\
\hline Moćan ${ }^{\mathrm{a}}$ & 4.75 & 1.53 & Ne koristi grube riječi & 4.56 & 1.69 \\
\hline Ima sposobnosti vođe ${ }^{a}$ & 4.74 & 1.40 & Ima sposobnosti vođe ${ }^{a}$ & 4.27 & 1.48 \\
\hline lako donosi odluke & 4.24 & 1.55 & Osjetljiva na tuđe potrebe & 4.26 & 1.63 \\
\hline Dominantan & 4.20 & 1.64 & Popustljiva & 4.16 & 1.48 \\
\hline Popustljiv & 4.12 & 1.22 & Dominantna & 4.02 & 1.59 \\
\hline Takmičarski nastrojen & 3.81 & 1.64 & Lako donosi odluke & 4.01 & 1.59 \\
\hline Laskav & 3.76 & 1.59 & Laskava & 3.76 & 1.47 \\
\hline Ponaša se kao vođa & 3.25 & 1.77 & Individualista & 3.34 & 1.80 \\
\hline Djetinjast & 3.12 & 1.74 & Djetinjast & 3.34 & 1.71 \\
\hline Individualista & 3.05 & 1.53 & Ponaša se kao vođa & 3.33 & 1.66 \\
\hline Stidljiv & 2.85 & 1.44 & Stidljiva & 3.21 & 1.43 \\
\hline Ženstven & 2.38 & 1.85 & Muževna & 2.68 & 2.08 \\
\hline Naivan & 1.64 & 1.00 & Agresivna & 2.41 & 1.68 \\
\hline Agresivan & 1.58 & 1.16 & Naivna & 1.76 & 1.02 \\
\hline
\end{tabular}

Napomene. $M$ - aritmetička sredina; $S D$ - standardna devijacija. ${ }^{\text {a }}$ - ajtemi koji čine faktor Socijalna dominacija; ${ }^{\text {b }}$ - ajtemi koji čine faktor Emotivna ekspresivnost.

Kako bi se stekla jasnija slika o njihovim izborima, razlike između polova sagledane su preko Welch-ove verzije $t$-testa (za racionalizaciju odabranog postupka v. npr. Delacre et al., 2017; de Winter \& Dodou, 2010; Norman, 2010). 
Nakon primijenjenih korekcija za višestruka poređenja (Benjamini \& Hochberg, 1995) identifikovano je nekoliko značajnih efekata (Tabela 2). Najočiglednija odstupanja zabilježena su u pogledu svojstava koja odgovaraju stereotipnim preferencijama muškaraca i žena - mladići zamišljaju ženstvenu partnerku, a djevojke muževnog partnera. Razmatranjem razlika samo u svjetlu karakteristika koje su ispitanici u prosjeku posmatrali najpoželjnijim, uočava se da je djevojkama posebno važna samostalnost partnera. Djevojke, osim toga, u nešto većoj mjeri očekuju i razumijevanje od svog partnera. S druge strane, i jedni i drugi najmanje priželjkuju da njihov partner bude naivan i agresivan, s tim da su djevojke prilično isključivije kada je riječ o agresiji. Ostale razlike tiču se obilježja koja ispitanicima nisu od velikog značaja, pri čemu intenziteti razlika ne prelaze granicu umjerene veličine (Cohen, 1988).

Tabela 2

Razlike između djevojaka i mladića u pogledu izbora karakteristika idealnog partnera

\begin{tabular}{lccc}
\hline Karakteristike & $d f$ & $t$ & $d$ \\
\hline Ženstvenost & 248 & $19.86^{* * *}$ & 2.35 \\
Muževnost & 215 & $-15.96^{* * *}$ & 1.94 \\
Samostalnost & 257 & $-4.98^{* * *}$ & 0.60 \\
Agresivnost & 236 & $4.75^{* * *}$ & 0.58 \\
Takmičarska nastrojenost & 275 & $3.77^{* * *}$ & 0.45 \\
Nekorišćenje grubih riječi & 270 & $-3.66^{* * *}$ & 0.44 \\
Sposobnost da se ublaži tuđa povrijeđenost & 241 & $-3.38^{* *}$ & 0.41 \\
Osjetljivost na tuđe potrebe & 269 & $-2.99^{*}$ & 0.36 \\
Posjedovanje sposobnosti vođe & 273 & $-2.72^{*}$ & 0.33 \\
Posjedovanje razumijevanja & 275 & $-2.66^{*}$ & 0.32 \\
\hline
\end{tabular}

Napomene. $d f$ - stepeni slobode; $t$ - vrednost t-testa; $d$ - veličina efekta.

${ }^{*} p<.05 .{ }^{* *} p<.01 .{ }^{* * *} p<.001$.

Razmatranjem preferencija u svjetlu faktora koji su izdvojeni konfirmativnom faktorskom analizom BSRI inventara, mladići, $M_{\mathrm{sd}}=5.54, S D_{\mathrm{sd}}=0.68$; $M_{\mathrm{ee}}=6.05, S D_{\mathrm{ee}}=0.64 ; t(134)=-7.91, p<.001, d=0.68, \mathrm{i}$ djevojke, $M_{\mathrm{sd}}=5.75$, $S D_{\text {sd }}=0.62 ; M_{\text {ee }}=6.22, S D_{\text {ee }}=0.57 ; t(143)=-8.30, p<.001, d=0.69$, u prosjeku snažnije preferiraju emotivno ekspresivnije nego socijalno dominantnije partnere, s tim da djevojke više nego mladići od svojih idealnih partnera očekuju izraženu i socijalnu dominaciju, $t(271)=2.76, p<.01, d=0.33$, i emotivnu ekspresivnost, $t(267)=2.38, p<.05, d=0.29$. 


\section{Osobine idealnih partnera i dimenzije afektivne vezanosti}

Kada je riječ o procjeni kvaliteta afektivne vezanosti, djevojke, $M_{\text {ank }}=$ $55.72, S D_{\text {ank }}=17.91 ; M_{\mathrm{izb}}=52.88, S D_{\mathrm{izb}}=13.77$, i mladići, $M_{\mathrm{ank}}=57.44, S D_{\mathrm{ank}}=$ $17.97 ; M_{\mathrm{izb}}=54.03, S D_{\mathrm{izb}}=15.77$, u prosjeku se ne razlikuju značajno na osnovu izraženosti anksioznosti, $t(276)=0.80, p=.43, d=0.10$, i izbjegavanja, $t(266)$ $=0.67, p=.51, d=0.08$. Vrijednosti na objema dimenzijama nalaze se ispod teorijske granice (72), što upućuje na to da mladi u partnerskim relacijama, $u$ prosjeku, iskazuju tendenciju ka sigurnoj vezanosti.

Regresionim analizama je ispitan potencijalni efekat afektivne vezanosti, tj. testirano je da li se preferencije prema karakteristikama idealnih partnera mogu objasniti izraženošću dimenzija anksioznosti i izbjegavanja. Kao kriterijumi su izabrani sumacioni skorovi na faktorima redukovanog BSRI modela - socijalnoj dominaciji i emotivnoj ekspresivnosti, a u svojstvu prediktora korišćene su dimenzije afektivnog vezivanja - anksioznost i izbjegavanje. Rezultati pokazuju (Tabela 3) da su dimenzije afektivnog vezivanja statistički značajni prediktori i socijalne dominacije i emotivne ekspresivnosti idealnih partnera, s tim da je intenzitet predikcije osjetno veći u slučaju emotivne ekspresivnosti (19\% naspram 6\% objašnjene varijanse). Pritom niže izbjegavanje i niža anksioznost predviđaju višu preferenciju prema socijalnoj dominaciji, dok niže izbjegavanje i viša anksioznost predviđaju višu preferenciju prema emotivnoj ekspresivnosti.

Provjereno je i da li pol ispitanika moderira relacije između varijabli. Oba regresiona modela ponašaju se funkcionalno ekvivalentno na poduzorcima muškaraca i žena, tj. razlike u regresionim koeficijentima za muškarce i žene $(\Delta \beta)$ ne dostižu nivo statističke značajnosti $(\Delta p)$, što znači da pol ne mijenja veze dimenzija afektivnog vezivanja sa preferencijom prema dominaciji i ekspresivnosti. Jedini izuzetak od ovoga odnosi se na relaciju anksioznosti sa preferiranom socijalnom dominacijom, čiji je regresioni koeficijent višeg intenziteta na poduzorku mladića $\left(\beta_{\mathrm{M}}=-.28\right)$ nego na poduzorku djevojaka $\left(\beta_{D}=-.04\right)$, što znači da je kod mladića viši nivo anksioznosti praćen snažnijom preferencijom prema nižoj socijalnoj dominaciji Ipak, ova se razlika nalazi na samoj granici konvencionalne statističke značajnosti, pa se ovo može smatrati samo naznakom tendencije, a ne njenom potvrdom. 
Tabela 3

Predikcija socijalne dominacije i emotivne ekspresivnosti na osnovu dimenzija afektivnog vezivanja i procjena razlike u regresionim modelima na poduzorcima muškaraca i žena

\begin{tabular}{lcccccccc}
\hline & \multicolumn{3}{c}{ Socijalna dominacija } & \multicolumn{3}{c}{ Emotivna ekspresivnost } \\
\cline { 2 - 8 } Prediktori & \multicolumn{3}{c}{$R^{2}=.06$} & \multicolumn{2}{c}{$\begin{array}{c}\text { Polne razlike u } \\
\text { predikciji }\end{array}$} & $R^{2}=.19$ & \multicolumn{2}{c}{$\begin{array}{c}\text { Polne razlike u } \\
\text { predikciji }\end{array}$} \\
\cline { 2 - 8 } & $\beta$ & $p$ & $\begin{array}{c}\Delta \beta \\
(|M-D|)\end{array}$ & $\begin{array}{c}\Delta p \\
(\mid M-D)\end{array}$ & $\beta$ & $p$ & $\begin{array}{c}\Delta \beta \\
(|M-D|)\end{array}$ & $\begin{array}{c}\Delta p \\
(|M-D|)\end{array}$ \\
\cline { 2 - 8 } Izbjegavanje & -.14 & .04 & .06 & .46 & -.44 & $<.01$ & .05 & .69 \\
Anksioznost & -.16 & .01 & .24 & .06 & .21 & $<.01$ & .01 & .95 \\
\hline
\end{tabular}

Napomene. $R^{2}$ - koefecijent multiple determinacije; $\beta$ - parcijalni doprnos predikotra; $p$ - nivo značajnosti. Svi $p$ i $\Delta p$ statistici dobijeni su postupkom samouzorkovanja zasnovanom na $k=5000$ simuliranih matrica.

\section{Diskusija}

Ovo istraživanje sprovedeno je kako bi se ispitalo koje psihološke karakteristike idealnog partnera vrednuju muške i ženske osobe u ranoj odrasloj dobi te kako bi se se utvrdilo mogu li se potencijalne razlike u preferencijama prema osobinama idealnog partnera objasniti na osnovu izraženosti dimenzija afektivne vezanosti - anksioznosti i izbjegavanja.

U skladu sa očekivanjima i trendovima već uočenim u prethodnim studijama (Botwin et al., 1997; Fletcher et al., 1999; Lippa, 2007; Simpson et al., 2001), nalazi pokazuju da su djevojke i mladići uglavnom usaglašeni kad je riječ o stepenu poželjnosti većine osobina koje čine sadržaj inventara BSRI. Iako je zabilježeno snažnije preferiranje ekspresivnih karakteristika, idealan partner opisuje se preko kombinacije osobina koje se tradicionalno pripisuju jednom odnosno drugom polu, a što je ujedno i indirektna potvrda nalaza da postoji diskrepanca između sagledavanja idealnog partnera i stereotipnog posmatranja muškarca i žene. Naime, idealan partner opisuje se kao osoba koju karakterišu odanost, pozitivnost, razumijevanje, ljubaznost, nježnost, ljubav prema djeci, samostalnost, ambicioznost, snažna ličnost i asertivnost. Ovakva kompleksna slika poželjnog partnera odgovara konceptu tzv. psihološke androginosti, koji je uvela Sandra Bem (1974). Ona i njeni saradnici uočili su da, u poređenju sa onima koji posjeduju isključivo osobine što se tipično pripisuju jednom polu, pojedinci sa zastupljenom psihološkom androginošću imaju izražene i ekspresivne i instrumentalne karakteristike, pa samim tim pokazuju veću fleksibilnost mišljenja i ponašanja te širok spektar psiholoških kompetencija, što im omogućava da se efikasnije prilagođavaju novim situacijama (npr. Bem \& Lenney, 1976). Zbog svega toga, takve osobe su u istraživanjima 
već prepoznate kao najprikladniji partneri za ljubavne veze (Green \& Kenrick, 1994).

Kada se osobine idealnih partnera posmatraju na nivou opštijih dimenzija, ustanovljeno je da djevojke i mladići poželjnijim idealnim partnerima smatraju emotivno ekspresivnije nego socijalno dominantnije osobe, čime je potvrđena i hipoteza o snažnijoj favorizaciji ekspresivnih u odnosu na instrumentalne osobine. Objašnjenje ovakvih rezultata moglo bi se bazirati na nalazima istraživanja o uticaju dominantnog ponašanja jednog partnera na doživljaj zadovoljstva vezom drugog partnera (Sadikaj et al., 2016). Sadikaj i saradnici (2016) od ispitanika su tražili da dvadeset dana svakodnevno izvještavaju o interakcijama sa svojim partnerom. Tako su utvrdili da su nezadovoljstvu vezom sklonije osobe čiji su partneri bili socijalno dominantniji, jer su često preuzimali kontrolu nad situacijom i time ugrožavali doživljaj autonomnosti svojih partnera. Stoga nije neobično da se i u našem slučaju poželjnijim partnerima smatraju emocionalno dostupne osobe. Takva preferencija prema emotivno ekspresivnijim partnerima mogla bi se posmatrati i kao indirektna potvrda nalaza iz oblasti afektivnog vezivanja, koji ukazuju na to da postoji tendencija ka biranju partnera sa sigurnim stilom vezanosti (Mikulincer \& Shaver, 2016). Naime, osobine koje čine faktor emotivne ekspresivnosti, poput: brižnosti, razumijevanja, nježnosti i topline, ujedno su i tipične karakteristike osoba sa sigurnim stilom vezanosti. Takve osobe su sklone konstruktivnom i emocionalno otvorenom stilu komuniciranja u partnerskim relacijama (Domingue \& Mollen, 2009), što ih takođe čini poželjnim partnerima.

Kada se sagledaju polne razlike, rezultati pokazuju da djevojke, u odnosu na mladiće, nešto više cijene samostalnost i razumijevanje, a svoje idealne partnere opisuju preko viših vrijednosti na mjerama poželjnosti socijalne dominacije i emotivne ekspresivnosti. Ta tendencija, tj. nešto veća izbirljivost djevojaka, već je zabilježena u istraživanjima (npr. Botwin et al., 1997) i najčešće se tumači preko teorije roditeljskog ulaganja. Pošto žene imaju ograničenije reproduktivne resurse i više se investiraju u svoje potomstvo nego muškarci, po svojoj prirodi su izbirljivije i zahtjevnije pri selekciji partnera (Trivers, 1972).

U istraživanju je procjenjivan i kvalitet afektivne vezanosti samih ispitanika, a pritom je uočena tendencija ka sigurnoj vezanosti. Ona nije nimalo neobična s obzirom na to da je, prema rezultatima mnogih studija, sigurna vezanost tipično najzastupljenija (Stefanović Stanojević, 2011). U ovom slučaju to je još manje neobično, budući da je riječ o mladim ljudima, koji tek grade svoje partnerske odnose, pa se i moglo očekivati da oni smatraju kako nemaju pretjeran strah od odbacivanja i napuštanja, odnosno doživljaj neprijatnosti izazvan intimnošću u partnerskim relacijama. Svakako, ne treba zanemariti ni mogućnost da sklonost mladih ka idealizaciji partnerskih odnosa (Montgomery, 2005) doprinosi tome da svoju vezanost vide sigurnijom nego što zaista jeste.

Rezultati ovog istraživanja sugerišu da se uključivanjem koncepta afektivne vezanosti $u$ ispitivanje preferencija prema određenim svojstvima ideal- 
nih partnera dobija nešto potpunija slika o izborima osoba u ranoj odrasloj dobi. Naime, dimenzije afektivnog vezivanja djevojaka i mladića pokazale su se kao statistički značajni prediktori preferencije prema osobinama idealnog partnera, nešto slabije prema onima koje čine faktor socijalne dominacije nego onima koje čine faktor emotivne ekspresivnosti. Tako višu preferenciju prema socijalnoj dominaciji predviđaju niže izbjegavanje i niža anksioznost, dok višu preferenciju prema emotivnoj ekspresivnosti predviđaju niže izbjegavanje i viša anksioznost. Dakle, pojedinci koji u manjoj mjeri procjenjuju kako im je neprijatno otvarati se u partnerskim odnosima, zavisiti od sopstvenog partnera i dopustiti da on zavisi od njih (tj. niže izbjegavanje) manje će biti isključivi kad je riječ o ovom izboru, pošto će birati i osobe koje otvorenije izražavaju svoje emocije, ali i one koje su dominantnije u društvenim odnosima. Drugačije rečeno, pozitivnija slika o drugima podrazumijeva, očekivano, lakše prihvatanje osoba sa izraženijim i emotivno ekspresivnim i socijalno dominantnim osobinama. Kada je riječ o dimenziji anksioznosti, osobe koje imaju pozitivniju sliku o sebi u partnerskim relacijama (tj. niža anksioznost) preferiraju socijalno dominantnije partnere. Ovo bi se moglo objasniti time što se one ne plaše odbacivanja i napuštanja, odnosno nemaju preveliku potrebu za bliskošću, podrškom, uvjeravanjem u ljubav i sl., pa radije biraju partnere koji su snažne ličnosti, ambiciozni, asertivni itd. S druge strane, osobe sa višom anksioznošću, tj. snažnijim uvjerenjem da ne zaslužuju ljubav svog partnera i strahom da će biti ostavljene, preferiraju one koji otvoreno iskazuju emocije, jer bi oni, kao takvi, prije mogli zadovoljiti njihove veoma izražene potrebe za bliskošću, pripadanjem i čestim uvjeravanjem u ljubav.

Nije utvrđeno da veza dimenzija afektivnog vezivanja i preferencije prema socijalnoj dominaciji odnosno emotivnoj ekspresivnosti zavisi od pola, ali se na poduzorku mladića ipak javila naznaka toga da je viši nivo anksioznosti praćen nešto snažnijom preferencijom prema nižoj socijalnoj dominaciji. Razlog bi moglo biti to da se slika o sebi kod mladića popravlja biranjem submisivnijih partnerki. Međutim, ova tendencija nije izražena do nivoa koji opravdava odbacivanje nulte hipoteze o postojanju polnih razlika i zahtijeva dodatnu provjeru na većem uzorku. Treba imati u vidu i da je uzorak istraživanja specifičan, pošto su ispitanike činili isključivo studenti. Moguće je da bi se uočena tendencija jasnije očitovala na manje specifičnom uzorku, koji bi uključio i nešto starije ispitanike.

\section{Zaključak}

Ovim istraživanjem identifikovane su psihološke karakteristike idealnog partnera koje vrednuju muške i ženske osobe u ranoj odrasloj dobi. Uvođenjem koncepta afektivnog vezivanja dodatno je osvijetljen izbor ovih osobina, budući da su uočene različite preferencije zavisno od izraženosti dimenzije anksioznosti odnosno izbjegavanja. Tako je i empirijski potvrđeno da se kara- 
kteristike poželjnog partnera i kvalitet afektivnog vezivanja mogu dovesti u direktnu vezu. Međutim, kako bi se upotpunio uvid u preferencije prema osobinama idealnog partnera, trebalo bi da se u nekim budućim istraživanjima u razmatranje uzmu i drugi aspekti, npr. fizički izgled, interesovanja, stavovi. Takođe bi trebalo proširiti uzorak tako da obuhvati i neheteroseksualne i osobe u drugim životnim dobima, pored rane odrasle, čime bi se mogla steći jasnija slika o ovim preferencijama u opštoj populaciji i u različitim periodima života.

\section{Reference}

Abele, A. E., \& Wojciszke, B. (2007). Agency and communion from the perspective of self versus others. Journal of Personality and Social Psychology, 93(5), 751-763. https://doi.org/10.1037/0022-3514.93.5.751

Atari, M., \& Jamali, R. (2016). Dimensions of women's mate preferences. Evolutionary Psychology, 14(2), 1-10. https://doi. org/10.1177/1474704916651443

Bartholomew, K., \& Horowitz, L. M. (1991). Attachment styles among young adults: A test of a four-category model. Journal of Personality and Social Psychology, 61(2), 226-244. https://doi.org/10.1037/0022-3514.61.2.226

Bem, S. L. (1974). The measurement of psychological androgyny. Journal of Consulting and Clinical Psychology, 42(2), 155-162.https://doi.org/10.1037/ h0036215

Bem, S. L. (1981). A manual for the Bem sex role inventory. Consulting Psychologist Press.

Bem, S. L., \& Lenney, E. (1976). Sex typing and the avoidance of crosssex behavior. Journal of Personality and Social Psychology, 33(1), 48-54. https:// doi.org/10.1037/h0078640

Benjamini, Y., \& Hochberg, Y. (1995). Controlling the false discovery rate: A practical and powerful approach to multiple testing. Journal of the Royal Statistical Society: Series B (Methodological), 57(1), 289-300. https://doi. org/10.1111/j.2517-6161.1995.tb02031.x

Bosak, J., Eagly, A., Diekman, A., \& Sczesny, S. (2017). Women and men of the past, present, and future: evidence of dynamic gender stereotypes in Ghana. Journal of Cross-Cultural Psychology, 49(1), 115-129. https://doi. org/10.1177/0022022117738750

Botwin, M. D., Buss, D. M., \& Shackelford, T. K. (1997). Personality and mate preferences: Five factors in mate selection and marital satisfaction. Journal of Personality, 65(1), 107-136. https://doi.org/10.1111/j.1467-6494.1997. tb00531.x

Boxer, C. F., Noonan, M. C., \& Whelan, C. B. (2013). Measuring mate preferences. Journal of Family Issues, 36(2), 163-187. https://doi. org/10.1177/0192513x13490404 
Brennan, K. A., Clark, C. L., \& Shaver, P. R. (1998). Selfreport measurement of adult attachment: An integrative overview. In J. A. Simpson \& W. S. Rholes (Eds.), Attachment theory and close relationships (pp. 46-76). Guilford Press.

Brumbaugh, C. C., Baren, A., \& Agishtein, P. (2014). Attraction to attachment insecurity: Flattery, appearance, and status's role in mate preferences. Personal Relationships, 21(2), 288-308. https://doi.org/10.1111/ pere. 12032

Buss, D. M., Abbott, M., Angleitner, A., Asherian, A., Biaggio, A., BlancoVillasenor, A., ... \& Yang, K.-S. (1990). International preferences in selecting mates. Journal of Cross-Cultural Psychology, 21(1), 5-47. https://doi. org/10.1177/0022022190211001

Buss, D. M., Shackelford, T. K., Kirkpatrick, L. A., \& Larsen, R. J. (2001). A half century of mate preferences: The cultural evolution of values. Journal of Marriage and Family, 63(2), 491-503. https://doi.org/10.1111/j.17413737.2001.00491.x

Choi, N., \& Fuqua, D. R. (2003). The structure of the Bem sex role inventory: A summary report of 23 validation studies. Educational and Psychological Measurement, 63(5), 872-887. https://doi. org/10.1177/0013164403258235

Cohen, J. (1988). Statistical power analysis for the behavioral sciences (2nd ed.). Lawrence Erlbaum Associates.

De Winter, J. F. C., \& Dodou, D. (2010). Five-point Likert items: t test versus MannWhitney-Wilcoxon (Addendum added October 2012). Practical Assessment, Research and Evaluation, 15(11), 1-16. Retrieved from: https://pareonline. net/getvn.asp?v=15\&n=11

Delacre, M., Lakens, D., \& Leys, C. (2017). Why psychologists should by default use Welch's t-test instead of student's t-test. International Review of Social Psychology, 30(1), 92-101. https://doi.org/10.5334/irsp.82

Diekman, A. B., \& Eagly, A. H. (2000). Stereotypes as dynamic constructs: Women and men of the past, present, and future. Personality and Social Psychology Bulletin, 26(10), 1171-1188. https://doi.org/10.1177/0146167200262001

Domingue, R., \& Mollen, D. (2009). Attachment and conflict communication in adult romantic relationships. Journal of Social and Personal Relationships, 26(5), 678-696. https://doi.org/ 10.1177/0265407509347932

Feeney, J. A. (1999). Adult romantic attachment and couple relationships. In J. Cassidy \& P. R. Shaver (Eds.), Handbook of attachment: Theory, research, and clinical applications (pp. 355-377). Guilford Press.

Fiske, S. T., Cuddy, A. J. C., Glick, P., \& Xu, J. (2002). A model of (often mixed) stereotype content: Competence and warmth respectively follow from perceived status and competition. Journal of Personality and Social Psychology, 82(6), 878-902. https://doi.org/10.1037/0022-3514.82.6.878

Fletcher, G. J. O., Simpson, J. A., Thomas, G., \& Giles, L. (1999). Ideals in intimate relationships. Journal of Personality and Social Psychology, 76(1), 72-89. https://doi.org/10.1037/0022-3514.76.1.72 
Fraley, R. C., Waller, N. G., \& Brennan, K. A. (2000). An item response theory analysis of self-report measures of adult attachment. Journal of Personality and Social Psychology, 78(2), 350-365. https://doi.org/10.1037/00223514.78.2.350

Green, B. L., \& Kenrick, D. T. (1994). The attractiveness of gender-typed traits at different relationship levels: Androgynous characteristics may be desirable after all. Personality and Social Psychology Bulletin, 20(3), 244-253. https:// doi.org/10.1177/0146167294203002

Haines, E. L., Deaux, K., \& Lofaro, N. (2016). The times they are a-changing ... or are they not? A comparison of gender stereotypes, 40(3), 19832014. Psychology of Women Quarterly, 40(3), 353-363. https://doi. org/10.1177/0361684316634081

Hanak, N., \& Dimitrijevic, A. (2013). A Serbian version of modified and revised experiences in close relationships scale (SM-ECR-R). Journal of Personality Assessment, 95(5), 530-538. https://doi.org/10.1080/00223891.2013.778 271

Hazan, C., \& Shaver, P. R. (1987). Romantic love conceptualized as an attachment process. Journal of Personality and Social Psychology, 52, 511-524. https:// doi.org/10.1037/0022-3514.52.3.511

Holmes, B. M., \& Johnson, K. R. (2009). Adult attachment and romantic partner preference: A review. Journal of Social and Personal Relationships, 26(6-7), 833-852. https://doi.org/10.1177/0265407509345653

Hooper, D., Coughlan, J., \& Mullen, M. (2008). Structural equation modelling: Guidelines for determining model fit. Electronic Journal of Business Research Methods, 6(1), 53-60. https://doi.org/10.21427/D7CF7R

Kachel, S., Steffens, M. C., \& Niedlich, C. (2016). Traditional Masculinity and Femininity: Validation of a New Scale Assessing Gender Roles. Frontiers in Psychology, 7. https://doi.org/10.3389/fpsyg.2016.00956

Levy, G. D., Taylor, M. G., \& Gelman, S. A. (1995). Traditional and evaluative aspects of flexibility in gender roles, social conventions, moral rules, and physical laws. Child Development, 66, 515-531. https://doi.org/10.2307/1131594

Lippa, R. A. (2007). The preferred traits of mates in a cross-national study of heterosexual and homosexual men and women: An examination of biological and cultural influences. Archives of Sexual Behavior, 36(2), 193-208. https:// doi.org/10.1007/s10508-006-9151-2

Maznah, I., \& Choo, P. F. (1986). The Factor Structure of the Bern Sex-Role Inventory (BSRI). International Journal of Psychology, 21(1-4), 3141. https://doi.org/10.1080/00207598608247574

Mikulincer, M., \& Shaver, P. R. (2016). Attachment in adulthood: Structure, dynamics and change. Guilford Press.

Montgomery, M.J.(2005).Psychosocialintimacyandidentity.JournalofAdolescent Research, 20(3), 346-374. https://doi.org/10.1177/0743558404273118

Moreland, J. R., Gulanick, N., Montague, E. K., \& Harren, V. A. (1978). Some psychometric properties of the Bem sex-role inventory. 
Applied Psychological Measurement, 2(2), 249-256. https://doi. org/10.1177/014662167800200207

Norman, G. (2010). Likert scales, levels of measurement and the "laws" of statistics. Advances in Health Sciences Education, 15(5), 625-632. https:// doi.org/10.1007/s10459-010-9222-y

Pedhazur, E. J., \& Tetenbaum, T. J. (1979). Bem Sex Role Inventory: A theoretical and methodological critique. Journal of Personality and Social Psychology, 37(6), 996-1016. https://doi.org/10.1037/0022-3514.37.6.996

Rosseel, Y. (2012). lavaan: An R package for structural equation modeling. Journal of Statistical Software, 48(2), 1-36. https://doi.org/10.18637/jss. v048.i02

Sadikaj, G., Moskowitz, D. S., \& Zuroff, D. C. (2016). Negative affective reaction to partner's dominant behavior influences satisfaction with romantic relationship. Journal of Social and Personal Relationships, 34(8), 13241346. https://doi.org/10.1177/0265407516677060

Shackelford, T. K., Schmitt, D. P., \& Buss, D. M. (2005). Universal dimensions of human mate preferences. Personality and Individual Differences, 39(2), 447458. https://doi.org/10.1016/j.paid.2005.01.023

Simpson, J. A., Fletcher, G. J. O., \& Campbell, L. (2001). The structure and function of ideal standards in close relationships. In G. J. O. Fletcher \& M. Clark (Eds.), Blackwell Handbook of Social Psychology: Interpersonal Processes (pp. 86106). Oxford: Blackwell.

Snyder, J. K., Kirkpatrick, L. A., \& Barrett, H. C. (2008). The dominance dilemma: Do women really prefer dominant mates? Personal Relationships, 15(4), 425-444. https://doi.org/10.1111/j.1475-6811.2008.00208.x

Stefanović Stanojević, T. (2011). Afektivna vezanost: razvoj, modaliteti i procena. Filozofski fakultet u Nišu.

Trivers, R. L. (1972). Parental investment and sexual selection. In B. Campbell (Ed.), Sexual Selection and the Descent of Man 1871-1971 (pp. 136-179). Aldine.

Vuletić, G. i Vuletić, T. (2017). Opažanje današnjeg muškarca i osobine poželjnog partnera s obzirom na konstrukte maskulinosti i femininosti. Psihološka istraživanja, 20(2), 273-289. https://doi.org/10.5937/PsIstra1702273V

Waters, C. W., Waters, L. K., \& Pincus, S. (1977). Factor analysis of masculine and feminine sex-typed items from the Bem Sex-Role Inventory. Psychological Reports, 40(2), 567-570. https://doi.org/10.2466/pr0.1977.40.2.567 


\section{Prilog}

Tabela A

Faktorska zasićenja redukovanog dvofaktorskog BSRI modela

\begin{tabular}{|c|c|c|}
\hline \multirow{2}{*}{ Stavke } & \multicolumn{2}{|c|}{ Faktorska zasićenja } \\
\hline & Socijalna dominacija & Emotivna ekspresivnost \\
\hline Snažna ličnost & .77 & \\
\hline Ambiciozan & .70 & \\
\hline Spreman da zauzme stav & .66 & \\
\hline Asertivan & .63 & \\
\hline Samostalan & .61 & \\
\hline Samopouzdan & .51 & \\
\hline Moćan & .44 & \\
\hline Nezavisan & .44 & \\
\hline Ima sposobnosti vođe & .40 & \\
\hline Brižan & & .85 \\
\hline Ljubazan & & .74 \\
\hline Ima razumijevanja & & .73 \\
\hline Nježan & & .72 \\
\hline Topla osoba & & .70 \\
\hline Saosjećajan & & .69 \\
\hline Odan & & .63 \\
\hline Osjećajan & & .62 \\
\hline Pozitivan & & .62 \\
\hline Prijatan u komunikaciji & & .60 \\
\hline Voli djecu & & .59 \\
\hline $\begin{array}{l}\text { Spreman da ublaži } \\
\text { povrijeđenost }\end{array}$ & & .55 \\
\hline
\end{tabular}

Napomena. Iz zabele su izostavljeni koeficijenti niži od .30. 


\section{Dejan Kantar \\ Department of \\ Psychology, Faculty \\ of Philosophy, University of Banja \\ Luka}

\section{Marija Zotović \\ Department of \\ Psychology, Faculty \\ of Philosophy, University of Novi \\ Sad}

Siniša Subotić
Department of
Psychology \&
Faculty of Natural
Sciences and
Mathematics,
University of Banja
Luka

\section{SEX DIFFERENCES IN PREFERENCES FOR AN IDEAL PARTNER CHARACTERISTICS AND ROLE OF ATTACHMENT}

The first aim of this study was to examine which psychological characteristics of an ideal partner are valued by female and male individuals in the early adulthood. The second goal is to determine whether the potential differences in the preferences regarding the traits of an ideal partner can be predicted by attachment-related anxiety and attachment-related avoidance. A convinient sample comprised 279 heterosexual students (51.6\% girls), average age 20.33 years, who completed the Serbian Version of Modified and Revised Experiences in Close Relationships Scale (SM-ECR-R) and the Bem Sex-Role Inventory (BSRI), which was used as a measure of the desirable partner traits. The results show that females and males are mostly in agreement regarding the desirability of the ideal partner traits. They chose both expressive and instrumental traits, with a stronger preference for the former. Both females and males consider emotionally expressive individuals to be more desirable ideal partners, whith females describing their ideal partners through higher values on the measures of social dominance and emotional expressiveness.When individual differences are considered through two attachment dimensions, the results indicate that higher preference for social dominance is predicted by lower avoidance and lower anxiety, while higher preference for emotional expressiveness is predicted by lower avoidance and higher anxiety. This confirms the usefulness of the attachment theory in explaining the ideal partner traits preferences, although the usefulness is higher for the explaination of emotional expressiveness than social domination.

Key words: attachment dimensions, early adulthood, expressive traits, ideal partner, instrumental traits 